\title{
Cost Effectiveness of Growing Cotton Depending on Irrigation Source and Groundwater Salinity in the Ferghana Valley, Uzbekistan
}

\author{
Sherzod Muminov, Galina Stulina, Islom Rusiev \\ International Fund for the Aral Sea Saving, Interstate Coordination Water Commission, Scientific-Information Center, Tashkent, \\ Uzbekistan \\ Email: galina_stulina@mail.ru
}

How to cite this paper: Muminov, S., Stulina, G. and Rusiev, I. (2017) Cost Effectiveness of Growing Cotton Depending on Irrigation Source and Groundwater Salinity in the Ferghana Valley, Uzbekistan. Agricultural Sciences, 8, 729-742.

https://doi.org/10.4236/as.2017.88054

Received: June 15, 2017

Accepted: August 5, 2017

Published: August 8, 2017

Copyright (๑) 2017 by authors and Scientific Research Publishing Inc. This work is licensed under the Creative Commons Attribution International License (CC BY 4.0). http://creativecommons.org/licenses/by/4.0/

\begin{abstract}
Given article describes the current status of irrigated agriculture in the Ferghana province, Republic of Uzbekistan. Climatic, hydrogeological, and soil conditions and hydromodule zoning of the Water User Association (WUA) Oktepa Zilol were studied, and, on this basis, the farms growing cotton were selected. Variable and fixed costs and profitability of cotton-growing farms were analyzed. Based on the books of those farms, the crop budget was drawn up. Relationships between the profitability of cotton-growing farm and the irrigation sources used and soil fertility in the farm are explained. Finally, proposals for improvement of cotton production using various sources of irrigation under different degrees of groundwater salinity are provided.
\end{abstract}

\section{Keywords}

Irrigation, Groundwater, Drainage Water, Salinity, Costs, Revenue

\section{Introduction}

Ferghana province (Figure 1) belongs to the area of ancient irrigated agriculture in Uzbekistan. By the beginning of the XX century, more than 150,000 ha were irrigated here. That time irrigation system had no any engineering design, not to mention drainage constructions. At the same time, most of irrigated territory did not demand artificial draining [1]. By the mid of the XX century, about 250,000 ha were irrigated. Irrigation was expanded and covered new land areas, mostly in the zones of moderate and poor drainability, which was accompanied 


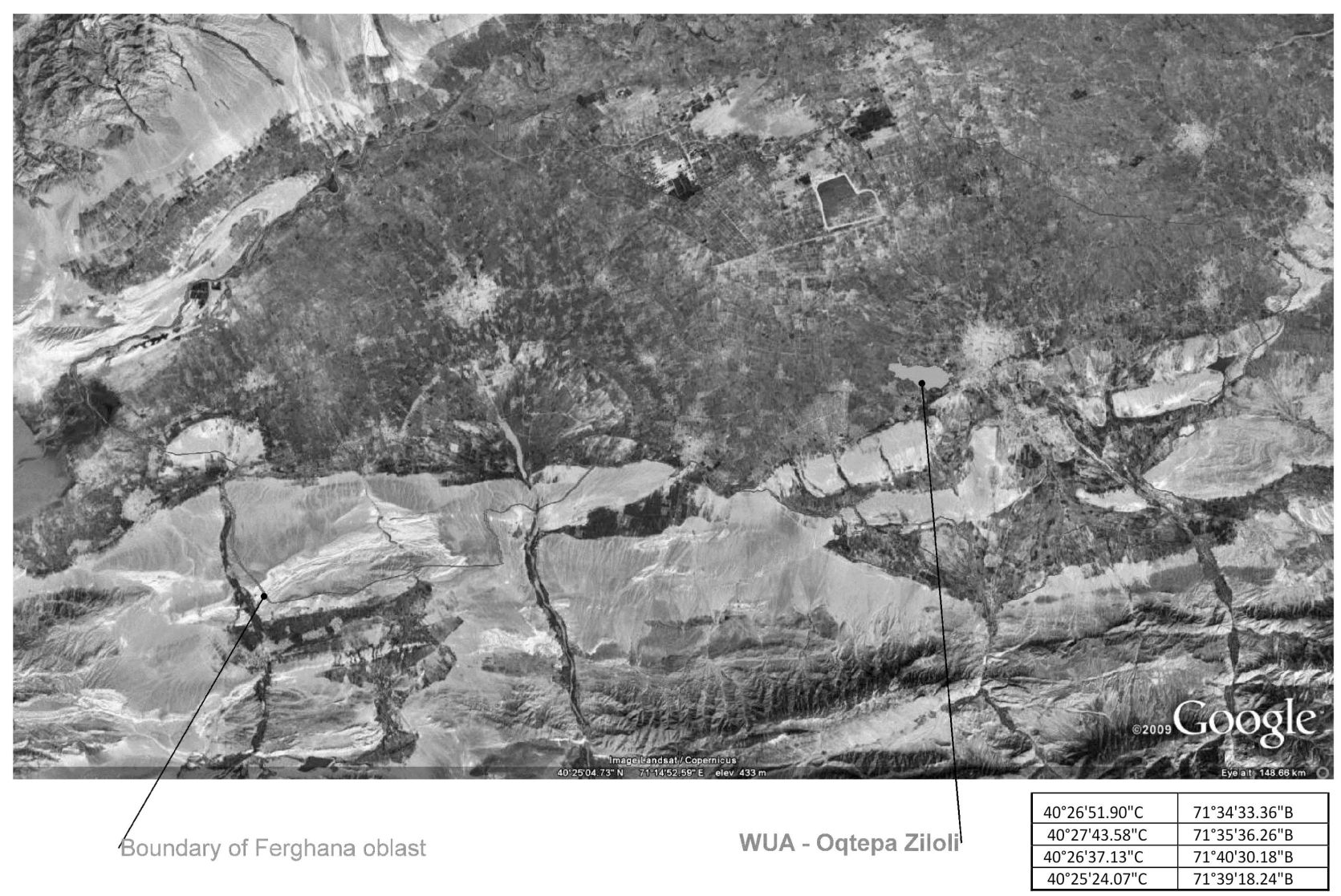

Figure 1. WUA Oktepa Zilol, Ferghana province.

by construction of inter- and rare on-farm collectors. However, such construction lacked primary relief drains; consequently, secondary salinization developed in case of shallow saline groundwater.

Development of adyr soil increased contribution from groundwater in the lower land. Thus, land conditions got worse. To prevent secondary salinization, vertical and horizontal drainage system was designed and constructed. 188,000 ha were equipped with drainage (67.5\% of irrigated area) in 1970, 261,000 ha $(73.2 \%)$ in 2000 , and 265,000 ha $(70 \%)$ in 2010. Main draining tracts in the province are the Achchikkul collector with the flow rate of $53 \mathrm{~m}^{3} / \mathrm{sec}, \mathrm{P}-3 \mathrm{col}$ lector $-21.2 \mathrm{~m}^{3} / \mathrm{sec}$, Shimoliy collector $-17.7 \mathrm{~m}^{3} / \mathrm{sec}$, Naynova collector -11.8 $\mathrm{m}^{3} / \mathrm{sec}$, Sokh Isfara collector $-12.5 \mathrm{~m}^{3} / \mathrm{sec}, \mathrm{K}-4$ collector $-8.8 \mathrm{~m}^{3} / \mathrm{sec}$, and Sari Juga collector-3.8 $\mathrm{m}^{3} / \mathrm{sec}[2]$.

In 2015 , cotton was grown on an area of 100,100 ha in the Ferghana province, with the average cotton yield reaching 28.6 centner/ha or 2.3 centner/ha lower than in 1991 [3]. The main cause of yield reduction is the higher level of drainage water salinity that resulted in salinization of land in the drained area.

Given the conditions of water scarcity and limitation, there is a need to use drainage water or its mixture with river-water for irrigation [4]. This practice has become especially important in the recent time due to climate change and 
severe droughts and has a direct effect on cost effectiveness of cotton production.

\section{Research Object}

Given research was carried out as part of the ICARDA Project (Project No. 1374) "Evaluate the effect of conjunctive use of canal and drainage water, different cropping patterns, and improved irrigation practices on control of salinity and waterlogging and delineate most efficient water management and agronomic practices" in the Ferghana province, Uzbekistan during As pilot sites the farms growing cotton were selected within the Water User Association (WUA) Oktepa Zilol located in Kushtepa district of Ferghana province. Researches and the analysis of results were carried out in 2014-2016.

\subsection{Climatic Conditions}

The climate in the region is sharply continental and dry with abundant heat and sunshine. Temperature regime is positive, with the average annual temperature of $13.9^{\circ} \mathrm{C}$. The coldest month is January with the average monthly temperature $-0.7^{\circ} \mathrm{C}$ and the absolute minimum temperature $-28^{\circ} \mathrm{C}$. The hottest month is July with the average monthly temperature $+27.3^{\circ} \mathrm{C}$ and the absolute maximum temperature $+43.5^{\circ} \mathrm{C}$. The rest of the year, but January and February, is with positive temperatures. The frost-free season lasts for 227 days. The region is very arid.

In 2015, the maximum of $+32^{\circ} \mathrm{C}$ was recorded in Andizhan weather station. Winter was not severe and the temperature did not fall below $+5^{\circ} \mathrm{C}$.

The non-growing season is characterized by high precipitation. The growing season is least humid, $57.2 \mathrm{~mm}$; most precipitation falls in April and May in the amount of $18-19 \mathrm{~mm}$, and minimum precipitation is recorded in July and August at $2-4 \mathrm{~mm}$.

There is heavy shower or hail in spring. That causes mudflow in adyrs, foothills and highlands. Snow pack is unstable. Snow pack lasts for 29 days. Prolonged heavy fog, hoarfrost, and ice-covered land are also typical for winter months. The average monthly wind speed is from 1.7 to $3.6 \mathrm{~m} / \mathrm{sec}$. The maximum wind speed amounts to $10-15 \mathrm{~m} / \mathrm{sec}$ and sometimes more than $15 \mathrm{~m} / \mathrm{sec}$. In 2015, wind regime was within the average annual indicators.

In the study region, evapotranspiration-total evaporation from free water surface and transpiration-amounts to $900 \mathrm{~mm}$ (Figure 2).

Air humidity deficit and high temperatures cause increased evaporation in summer. Thus, owing to high dryness in this region, agriculture may be developed only under artificial irrigation.

\subsection{Hydrogeological Conditions}

Geomorphologic conditions determined specific hydrogeological situation in Ferghana province: formation of high-pressure artesian water with inflow from 


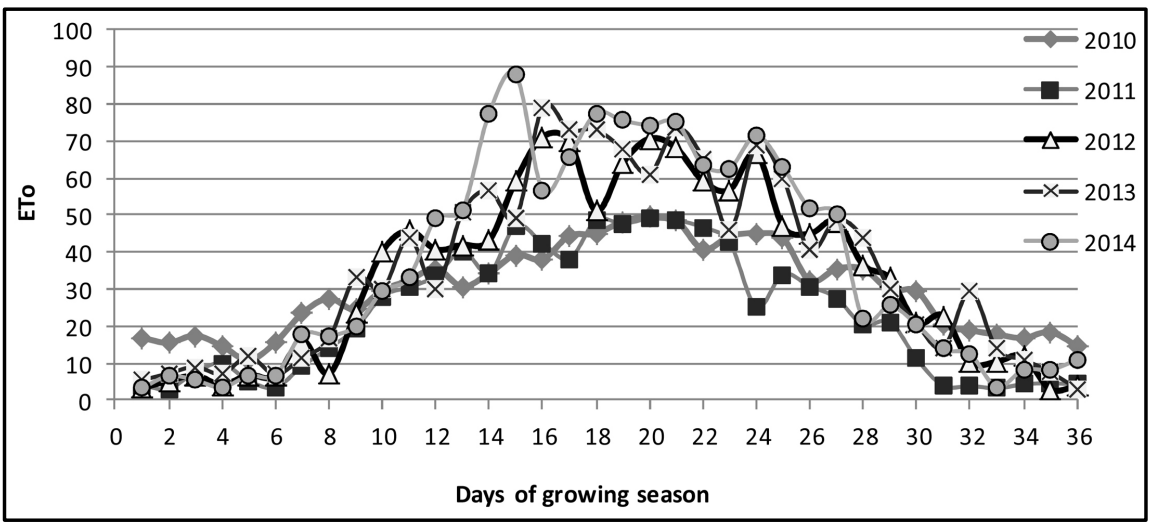

Figure 2. Potential evapotraspiration data, WUA Oktepa Zilol, Ferghana province.

the surrounding mountains and also saline shallow groundwater. Before the development of drainage systems, water table was up to $2 \mathrm{~m}$ everywhere, and the salinity of groundwater varied from $3-5$ to $10 \mathrm{~g} / \mathrm{l}$ and more. Piezometric heads are at the level of $0.2-0.95 \mathrm{~m}$ above water table everywhere. Groundwater recharge through overflow from confined aquifer in quaternary deposits of Central Ferghana varies from $2-3$ to $8-10$ thousand $\mathrm{m}^{3} / \mathrm{ha}$. Thus, groundwater is shallow, and substantial drainage flow is formed, i.e. drainage capacity increases.

In terms of natural drainability, the area of Central Ferghana is divided into 5 zones with:

- Intensive drainability. This zone spreads over foothill side, with deep groundwater;

- Moderate drainability. This zone spreads over upstream of the Big Fergana Canal (BFC) in the western part of the province;

- Poor drainability. This zone spreads between BFC and SFC;

- Very poor drainability. This zone spreads over central part of the province downstream of the BFC; and

- Drainless zone. This zone spreads over floodplain zone of the Syrdarya River.

Ferghana province has rather long unit length $(24-41 \mathrm{~m} / \mathrm{ha}$ per irrigated area) of subsurface drainage in 1970-2015. Alongside with horizontal drainage, vertical drainage wells were actively constructed and increased from 100 wells in 1970 and 1303 ones in 1995. However, their quantity dropped to 1131 in 2010 [1] [4] and even to 554 in 2015. In 2015, 38 vertical drainage wells were available in Kushtepa district.

This massive system of vertical and horizontal drainage provided substantial drainage salt-water outflow. In 1970-1975, the total drainage flow amounted to about $2554 \mathrm{Mm}^{3}$, while water withdrawal was $5078 \mathrm{Mm}^{3}$. Since 1980, drainage flow has got more or less stabilized at the level of $3000 \mathrm{Mm}^{3}$ per year, while the total water withdrawal was $5000 \mathrm{Mm}^{3}$ per year. By 2000-2015, both water withdrawal and the total drainage flow have decreased.

The share of the total drainage flow in water withdrawal of the Ferghana province varied from $40.7 \%$ in 1970 to $50.4 \%$ in 2000 and $58.1 \%$ in 2015 . Given 
the total water withdrawal and its salinity, degree of which increased from $0.4 \mathrm{~g} / \mathrm{l}$ to $0.7 \mathrm{~g} / \mathrm{l}$ in 2000 and $0.9 \mathrm{~g} / \mathrm{l}$ in 2015 , inflow of salts in the province changed from $2,285,500$ tons in 1970 to $3,600,200$ tons in 1985 , with the unit values of $17.7 \mathrm{t} / \mathrm{ha}$ and $15.8 \mathrm{t} / \mathrm{ha}$ a year, respectively. The average inflow of salts decreased to $11.4 \mathrm{t} / \mathrm{ha}$ a year by 2000 and to $6 \mathrm{t} / \mathrm{ha}$ a year by 2015 . The collected data shows that drainage flow and groundwater storage are quite significant for re-use and vary by year from 1200 to 1700 thousand $\mathrm{m}^{3}$ and from 1900 to 2900 thousand $\mathrm{m}^{3}$, respectively. At present, only $10 \%$ of these waters is used for irrigation (Figure 3).

The studied WUA Oktepa Zilol (Figure 1) is located in the subtropical foothill zone. The soil is comprised of meadow and sierozem soil that is formed on alluvial-proluvial deposits of alluvial cones.

In terms of hydrogeology, the study site is located in the area of shallow groundwater, including both artesian and non-artesian waters. The depth of groundwater varies from 1.2 to $2.1 \mathrm{~m}$ in loamy sand and loamy deposits. The network of hydrogeological and reclamation wells is constructed in the WUA, where water tables are measured every ten-day.

Groundwater salinity varies from 0.1 to $3.96 \mathrm{~g} / \mathrm{l}$ during the growing season. In terms of chemical composition, groundwater salinity is sulpthate-chloride and sulphate. High salinity is stagnant due to slight surface slope and poor outflow of groundwater.

Impermeable rock layer causes formation of artesian and sub-artesian water. Artesian waters lay at a depth of $120-200 \mathrm{~m}$ in sandy-gravel deposits. The unit well capacity is about $1 \mathrm{l} / \mathrm{sec}$. Water is fresh, with salinity of $0.55 \mathrm{~g} / \mathrm{l}$; it is used for irrigation. Chemical composition is sulphate-hydrocarbonate-calcic-magnesium.

The surface slope of groundwater is $0.002-0.0025$. This indicates to poor land drainabilty. Slight slopes and poor permeability of surface fine grained soil are the reasons for stagnant nature of groundwater and, because of its evaporation, salt accumulates in the soil and groundwater salinity increases. Groundwater is recharged mainly through percolation during watering, seepage losses and from

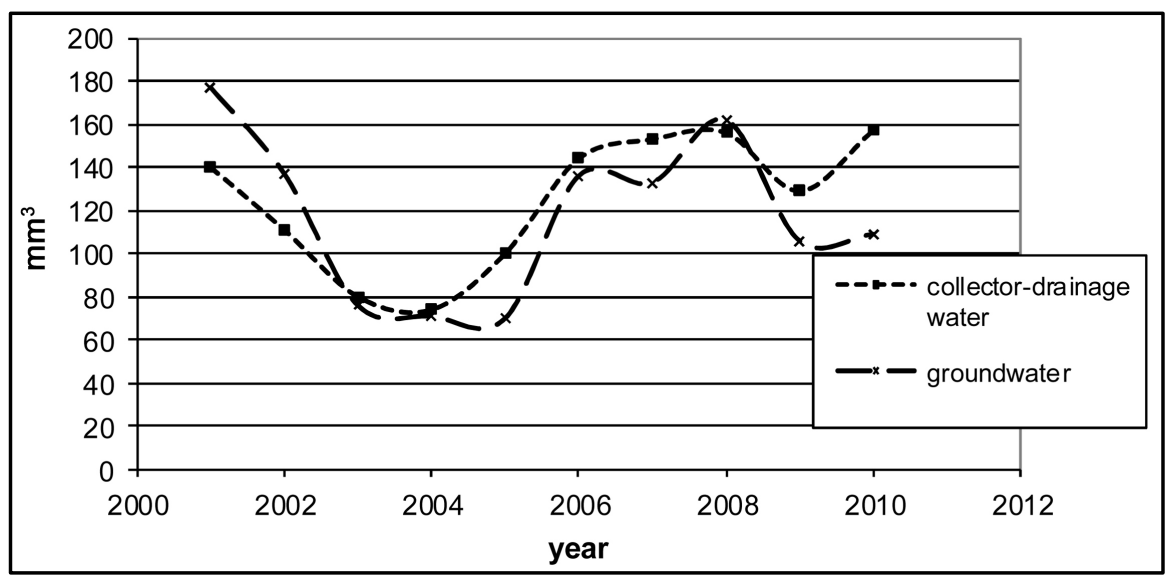

Figure 3. Use of collector-drainage water and groundwater for irrigation. 
deep confined aquifer. Groundwater recharge through precipitation is minor.

\section{Materials and Methods}

The research objective is formulated proceeding from the urgency of the issued related to limited nature of water and the need for alternative water use practices in the context of climate change. Here one deals with irrigation with saline water, analysis of variable and fixed costs and profitability of farms growing cotton using various irrigation sources under groundwater with different degrees of salinity, based on bookkeeping review of those farms. Proceeding from the results of the analysis of soil-climatic indicators and cost effectiveness of the farms growing cotton, scientifically and practically sound proposals are developed for the improvement of cotton production using various irrigation sources under different degrees of groundwater salinity.

Research questions can be detailed as follows:

- What effect do various irrigation sources have on variable and fixed costs of cotton production?

- How does the level of groundwater salinity impact on cost effectiveness of cotton production?

- Which of irrigation sources ensures highest profitability of cotton production?

Research options included the use of saline drainage water for irrigation and several other kinds of conjunctive use of drainage and canal water:

- water from vertical drainage wells used for permanent irrigation;

- same kind of water as above diluted with canal water;

- water pumped from collector in that time, when the plant is salt tolerant to medium saline water;

- slightly saline collector-drainage water (CDW) since the beginning of the growing season.

Within the WUA Oktepa Zilol, there is a pilot plot with sub-irrigation through backwater in drains.

The research options were implemented in 5 farms (Table 1).

The studied farms receive water from different sources: Pakhlavon Gulomjon

Table 1. Main indicators of selected farms.

\begin{tabular}{|c|c|c|c|c|c|}
\hline & $\begin{array}{c}\text { Pakhlavon } \\
\text { Gulomjon } \\
\text { (SFC) }\end{array}$ & $\begin{array}{c}\text { Abdullajon } \\
\text { (vertical } \\
\text { drainage) }\end{array}$ & $\begin{array}{c}\text { Nuritdin } \\
\text { Tanikulov } \\
\text { (CDW and } \\
\text { SFC) }\end{array}$ & $\begin{array}{c}\text { Bakhodir } \\
\text { Mirzaev } \\
(\mathrm{CDW})\end{array}$ & $\begin{array}{c}\text { Sharofiddin } \\
\text { Kuchkarali } \\
\text { Khasanov } \\
\text { (BFC) }\end{array}$ \\
\hline Study area, ha & 7.7 & 9.0 & 10.0 & 9.0 & 9.0 \\
\hline Yield, centner/ha & 31.2 & 30.0 & 33.6 & 28.4 & 30.6 \\
\hline $\begin{array}{c}\text { Quality score } \\
\text { attributed to soil }\end{array}$ & 81 & 73 & 62 & 41 & 53 \\
\hline Degree of salinity, $\mathrm{dS} / \mathrm{m}$ & 1.12 & 0.78 & 1.92 & 4.88 & 1.11 \\
\hline Water salinity, g/l & 0.5 & 0.7 & 0.7 & 3.88 & 0.6 \\
\hline
\end{tabular}


farm-from South-Ferghana canal (SFC); Abdullajon farm-from vertical drainage; Nuritdin Tanikulov farm-conjunctive use of CDW and water from SFC; Bakhodir Mirzaev farm-from CDW; and, Sharofiddin Kuchkarali Khasanov farm-from Big Ferghana Canal (BFC).

Irrigation water is delivered from various sources (Table 1), thus one may study application of water having different levels of salinity and the resulting effect on soil and plants. The cotton variety "Namangan 77 r-2" was grown in all the farms. The quality of soil fertility (quality score and degree of salinity) is also different in those farms (Table 1).

All these types of CDW use were compared in terms of yield, salinity, costs and benefits of cotton production.

The research consisted in: collection of data; field studies; laboratory studies; and, economic analysis of the results.

For the purposes of analysis the soil-climatic data on the Ferghana province and WUA Oktepa Zilol and the soil maps at a scale of 1:200,000, 1:50,000 and 1:10,000 were used.

- land cadastre data on soil fertility (quality score);

- data on groundwater level and salinity;

- soil salinity determined by soil sampling at the depths of $0-30 \mathrm{~cm}$ and 30 $70 \mathrm{~cm}$ and by further laboratory analysis for qualitative and quantitative content of salts;

- salinity of irrigation water, collector-drainage water and of water from vertical drainage wells determined by sampling and laboratory analysis;

- source information collected by talking with farmers and book-keepers of the selected farms;

- the books of these farms analyzed;

- crop budget drawn up for cotton using various sources of irrigation under different degrees of groundwater salinity.

\section{Research Results}

\subsection{Comparative Analysis of the Variable Costs}

The variable costs are the costs that depend on the volume of agricultural production in the farms. These are the inputs of the variable factors of crop production in the farms (Figure 4).

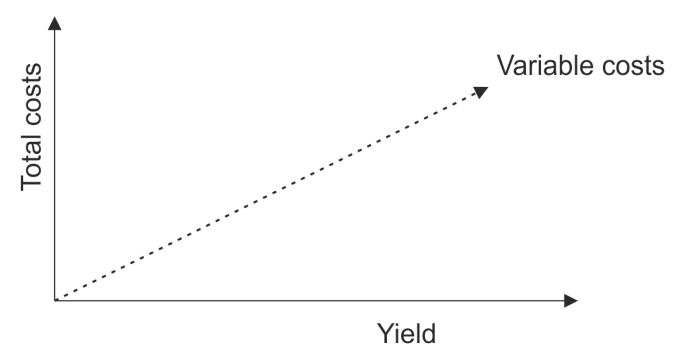

Figure 4. Variable costs of farms. 
Variable costs of the farms include:

- seeds cost;

- mineral and organic fertilizer costs;

- agrochemicals;

- fuels and lubricants;

- machine and equipment repair and maintenance;

- transportation of products;

- remuneration of hired workers and farm workers who are busy with harvesting and other kinds of activities related to the use of resources.

The variable costs always grow as the scale of production increases.

Taking into account the above mentioned methods for calculation of variable costs, we analyzed these costs in the selected farms. The analysis revealed that the variable costs of cotton growing in the selected farms varied from 9, 411.3 USD to 12,910.8 USD. High variable costs were observed in the Nuritdin Tanikulov farm. The unit variable costs were 133.3 - 143.5 USD/ha on average (Table 2).

As Figure 5 shows, the share of variable costs in the selected farms is the following: $32.2 \%-34.6 \%$ - manual labor, $26.7 \%-30.2 \%$ - mineral fertilizers, and $15.7 \%-16.9 \%$-machines and equipment.

Table 2. Structure of the variable cost in the selected farms, USD*.

\begin{tabular}{|c|c|c|c|c|c|c|c|c|c|c|}
\hline & \multicolumn{2}{|c|}{$\begin{array}{c}\text { Pakhlavon } \\
\text { Gulomjon } \\
\text { (SFC) }\end{array}$} & \multicolumn{2}{|c|}{$\begin{array}{c}\text { Abdullajon } \\
\text { (vertical } \\
\text { drainage) }\end{array}$} & \multicolumn{2}{|c|}{$\begin{array}{c}\text { Nuritdin } \\
\text { Tanikulov } \\
(\mathrm{CDW} \text { and SFC) }\end{array}$} & \multicolumn{2}{|c|}{$\begin{array}{c}\text { Bakhodir } \\
\text { Mirzaev } \\
(\mathrm{CDW})\end{array}$} & \multicolumn{2}{|c|}{$\begin{array}{c}\text { Sharofiddin } \\
\text { Kuchkarali } \\
\text { Khasanov } \\
\text { (BFC) }\end{array}$} \\
\hline & total & per 1 ha & total & per 1 ha & total & per 1 ha & total & per 1 ha & total & per 1 ha \\
\hline Seeds & 537.9 & 69.9 & 617.4 & 68.6 & 748.4 & 74.8 & 662.3 & 73.6 & 667.9 & 74.2 \\
\hline $\begin{array}{l}\text { Mineral } \\
\text { fertilizers }\end{array}$ & 2733.9 & 355.1 & 3106.5 & 345.2 & 3756.0 & 375.6 & 3255.8 & 361.8 & 2901.6 & 322.4 \\
\hline $\begin{array}{l}\text { Organic } \\
\text { fertilizers }\end{array}$ & 47.9 & 6.2 & 58.1 & 6.5 & 62.9 & 6.3 & 57.4 & 6.4 & 56.0 & 6.2 \\
\hline Agrochemicals & 397.0 & 51.6 & 462.0 & 51.3 & 540.4 & 54.0 & 471.8 & 52.4 & 479.8 & 53.3 \\
\hline $\begin{array}{l}\text { Fuel and } \\
\text { lubricants }\end{array}$ & 860.2 & 111.7 & 830.6 & 92.3 & 1175.5 & 117.5 & 961.7 & 106.9 & 1005.4 & 111.7 \\
\hline $\begin{array}{l}\text { Manual } \\
\text { labor }\end{array}$ & 3176.9 & 412.6 & 3586.6 & 398.5 & 4435.7 & 443.6 & 3478.9 & 386.5 & 3752.5 & 416.9 \\
\hline $\begin{array}{c}\text { Machines and } \\
\text { equipment }\end{array}$ & 1536.1 & 199.5 & 1781.8 & 198.0 & 2028.6 & 202.9 & 1768.9 & 196.5 & 1832.7 & 203.6 \\
\hline $\begin{array}{l}\text { Water } \\
\text { delivery }\end{array}$ & 39.4 & 5.1 & 65.6 & 7.3 & 69.9 & 7.0 & 57.7 & 6.4 & 62.9 & 7.0 \\
\hline Transportation & 82.1 & 10.7 & 53.0 & 5.9 & 93.4 & 9.3 & 83.1 & 9.2 & 100.7 & 11.2 \\
\hline Total & 9411.3 & 135.8 & $10,561.5$ & 130.4 & $12,910.8$ & 143.5 & $10,797.7$ & 133.3 & $10,859.6$ & 134.1 \\
\hline
\end{tabular}

${ }^{*}$ Currency exchange rates were downloaded as of January 28, 2016 from the web-site of the Central Bank of Uzbekistan: http://cbu.uz/uzc/arkhiv-kursov-valyut/dinamika-kursov-valyut/ [5]. 


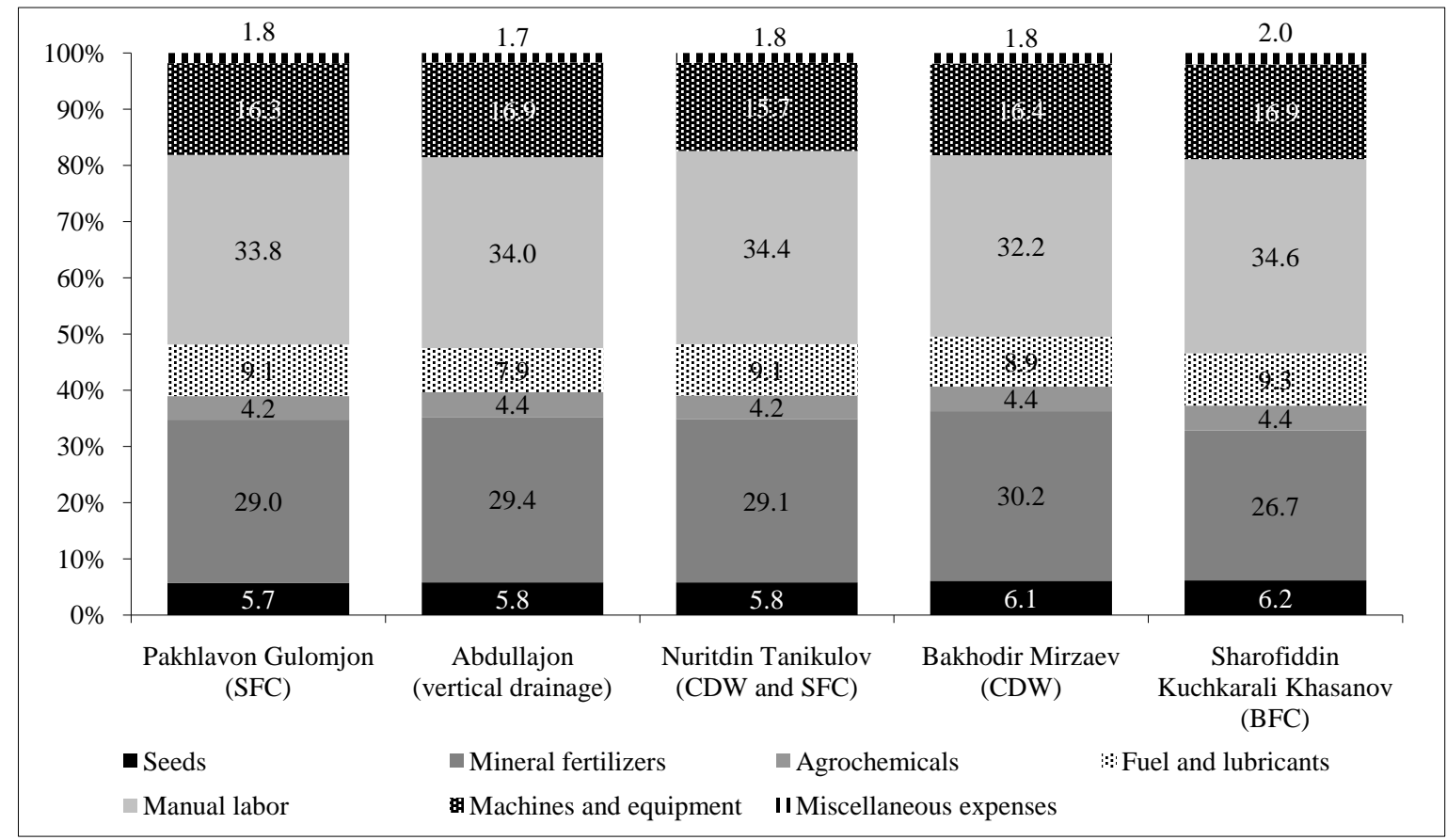

Figure 5. Shares of variable costs in the selected farms.

The difference in the variable costs between the selected farms is minor. The major difference is observed in the costs of manual labor and of machines and equipment. The prices for raw materials and inputs (seeds, mineral fertilizers, agrochemicals and fuel and lubricants) for growing cotton in the selected farms are the same. The reasons are the following: firstly, the prices for raw materials are fixed; secondly, these farms are provided with raw materials and inputs from specialized organizations as the production of raw cotton is the state's order and is funded through soft credits.

The cost of manual labor and of machines and equipment in the selected farms slightly varies. Moreover, the use of manual labor in the selected farms increased significantly. This caused high expenses of manual labor. The cost of manual labor in the selected farms is composed of the norm of labor use, availability of hired workers and their remuneration demands. At present, cotton growing farms use their own machines and equipment, as well as those of private owners and through services provided by the Machine and Tractor Fleet (MTF). The farmers used machine and equipment services of the private owners and MTF; however, they themselves provided fuel and lubricants for machines.

Water delivery costs varied depending on the water source. Thus, water delivery costs in the farms that received water from the collector-drainage network and vertical drainage wells were $20 \%-30 \%$ lower than the cost of water taken from SFC and BFC.

Taking into account the abovementioned indicators, mineral fertilizers and cultivation are actively applied in all the farms. These operations are also applied in the farms where water salinity is high, such as the Bakhodir Mirzaev farm, 
where irrigation water is taken from the collector-drainage network. These agronomic operations are supposed for short-term and allow achieving high yields in given year. However in the longer term, extra application of fertilizers do not contribute to high yield and, in contrary, lead to its decrease due to reduced soil fertility caused by frequent application of mineral fertilizers. In spite of this, organic fertilizers were insufficiently applied in the selected farms. The medium-term agronomic operations, in their turn, are aimed at bettering soil fertility and only then at increasing of cotton yield. The results of the medium-term operations can be observed only 3 - 4 years later.

\subsection{Comparative Analysis of Fixed Costs}

The fixed costs are the costs that do not depend on the volume of agricultural production. These are the costs of fixed factors of production (Figure 6).

The fixed costs of farms include:

- land tax;

- salary fund for permanent workers;

- payment of bank transactions;

- insurance payment for seeds and property;

- depreciation costs.

It should be underlined that the total fixed costs, being constant and not depending on production volume, may vary under the influence of other factors. Hence, if the prices rise, the total fixed costs also increase.

Taking into account the abovementioned method of calculation of the fixed costs, we analyzed the fixed costs. The analysis revealed that the major fixed costs in the selected farms were administrative costs (salary fund for permanent workers and so on). The unit administrative costs vary from 47.2 USD/ha to 62.0 USD/ha. High unit costs can be observed in the Nuritdin Tanikulov farm (CDF and SFC) -62.0 USD/ha on average-and in the Pakhlavon Gulomjon farm (SFC) - 50.2 USD on average (Table 3 ).

The high share of administrative costs is observed in such farms as Bakhodir Mirzaev (45.6\%), Nuritdin Tanikulov (45.4\%), and Sharofiddin Kuchkarali Khasanov (42.6\%) (Figure 7).

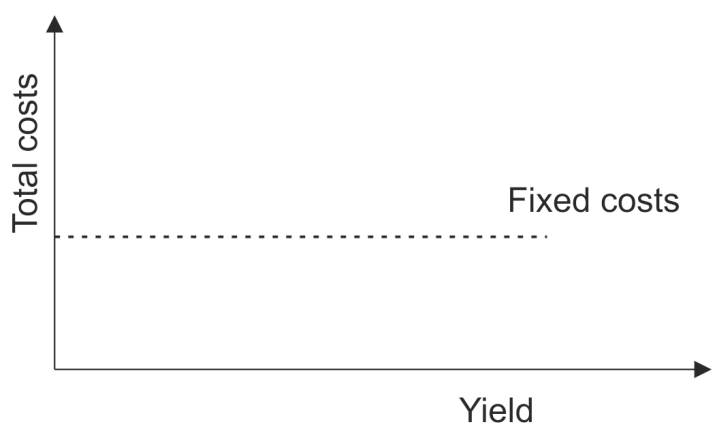

Figure 6. Fixed costs of the farms. 


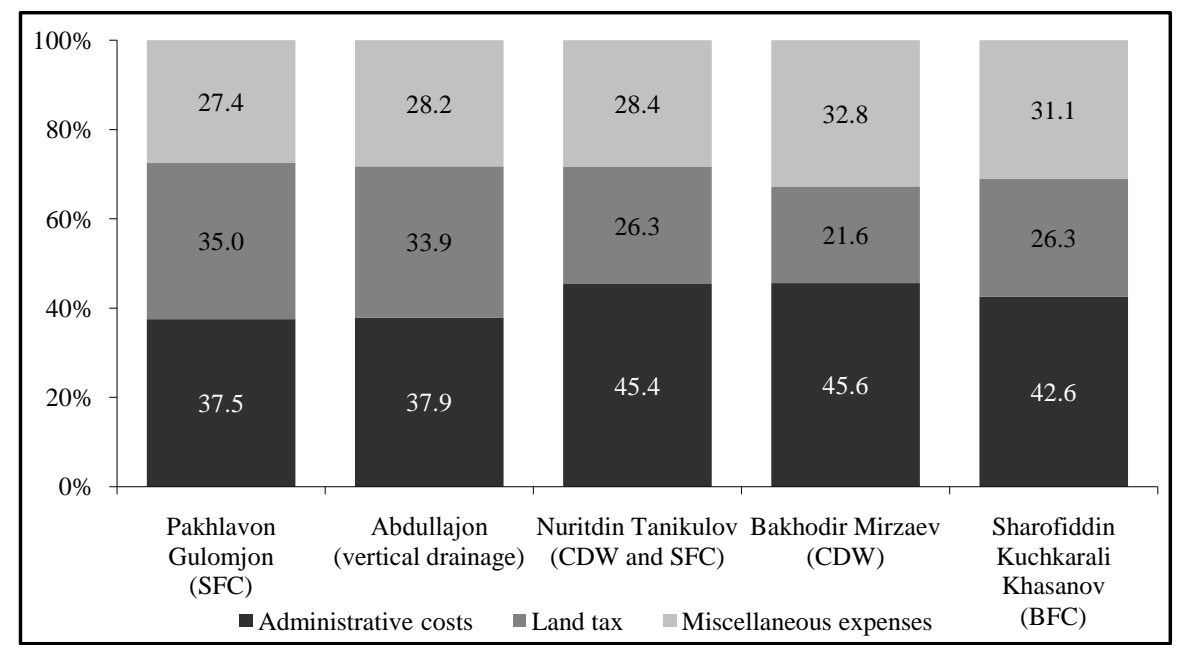

Figure 7. Shares of fixed costs in the selected farms.

Table 3. Structure of the fixed costs in the selected farms, USD*.

\begin{tabular}{|c|c|c|c|c|c|c|c|c|c|c|}
\hline & \multicolumn{2}{|c|}{$\begin{array}{l}\text { Pakhlavon } \\
\text { Gulomjon } \\
\text { (SFC) }\end{array}$} & \multicolumn{2}{|c|}{$\begin{array}{l}\text { Abdullajon } \\
\text { (vertical } \\
\text { drainage) }\end{array}$} & \multicolumn{2}{|c|}{$\begin{array}{c}\text { Nuritdin } \\
\text { Tanikulov } \\
(\mathrm{CDW} \text { and SFC) }\end{array}$} & \multicolumn{2}{|c|}{$\begin{array}{l}\text { Bakhodir } \\
\text { Mirzaev } \\
(\mathrm{CDW})\end{array}$} & \multicolumn{2}{|c|}{$\begin{array}{c}\text { Sharofiddin } \\
\text { Kuchkarali } \\
\text { Khasanov } \\
\text { (BFC) }\end{array}$} \\
\hline & total & $\begin{array}{l}\text { per } \\
1 \text { ha }\end{array}$ & total & $\begin{array}{l}\text { per } \\
1 \text { ha }\end{array}$ & total & $\begin{array}{l}\text { per } \\
1 \text { ha }\end{array}$ & total & $\begin{array}{l}\text { per } \\
1 \text { ha }\end{array}$ & total & $\begin{array}{l}\text { per } \\
1 \text { ha }\end{array}$ \\
\hline $\begin{array}{l}\text { Administrative } \\
\text { costs }\end{array}$ & 386.3 & 50.2 & 425.2 & 47.2 & 619.8 & 62.0 & 450.8 & 50.1 & 446.1 & 49.6 \\
\hline Land tax & 360.7 & 46.8 & 380.0 & 42.2 & 358.6 & 35.9 & 213.4 & 23.7 & 275.9 & 30.7 \\
\hline $\begin{array}{l}\text { Miscellaneous } \\
\text { expenses }\end{array}$ & 282.3 & 36.7 & 316.8 & 35.2 & 387.3 & 38.7 & 323.9 & 36.0 & 325.8 & 36.2 \\
\hline Total & 1029.3 & 44.6 & 1122.0 & 41.6 & 1365.7 & 45.5 & 988.1 & 36.6 & 1047.7 & 38.8 \\
\hline
\end{tabular}

${ }^{*}$ Currency exchange rates were downloaded as of January 28, 2016 from the web-site of the Central Bank of Uzbekistan: http://cbu.uz/uzc/arkhiv-kursov-valyut/dinamika-kursov-valyut/ [5].

Land taxation depends on condition of soil fertility. Thus, in the "Pakhlovon Gulomjon" farm (SFC) with the soil quality score of 81 , the land tax is 46.8 USD per ha on average, whereas in the "Bakhodir Mirzaev" farm (CDW) with the soil quality score of 41 - 23.7 USD per ha on average.

Miscellaneous expenses in the selected farms include the payments for bank transactions, insurance payments for seeds and property, and depreciation costs. They vary from 35.2 USD to 38.7 USD per ha.

Based on the results of the analysis of variable and fixed costs in the selected farms, the bellow findings can be made:

- in all farms the share of variable costs and fixed costs is $90 \%$ and $10 \%$, respectively;

- the share of manual labor, mineral fertilizers and of machines and equipment is high in the variable costs. 


\subsection{Comparative Analysis of Profitability}

The analysis shows that the high share of net profit is observed in the Nuritdin Tanikulov farm (irrigation water from CDW and SFC) - 131.3 USD/ha, and in the Sharofiddin Kuchkarali Khasanov farm (irrigation water from BFC) - 87.7 $\mathrm{USD} / \mathrm{ha}$. It worth mentioning that in the farms that receive water from the collector-drainage network production of cotton is unprofitable. In particular, in the Bakhodir Mirzaev farm, the indicator of unprofitability amounts to 35.1 USD/ha (Table 4).

Manual labor, land, and instruments of labor are essential conditions and factors for growing crops in the farm. Hence, agricultural inputs are the set of labor, land, and material resources to be used or usable for crop production.

Table 4. Cost effectiveness of cotton production in the selected farms*.

\begin{tabular}{|c|c|c|c|c|c|}
\hline Indicator & $\begin{array}{c}\text { Pakhlavon } \\
\text { Gulomjon } \\
\text { (SFC) }\end{array}$ & $\begin{array}{c}\text { Abdullajon } \\
\text { (vertical } \\
\text { drainage) }\end{array}$ & $\begin{array}{c}\text { Nuritdin } \\
\text { Tanikulov } \\
\text { (CDW and } \\
\text { SFC) }\end{array}$ & $\begin{array}{c}\text { Bakhodir } \\
\text { Mirzaev } \\
(\mathrm{CDW})\end{array}$ & $\begin{array}{c}\text { Sharofiddin } \\
\text { Kuchkarali } \\
\text { Khasanov } \\
\text { (BFC) }\end{array}$ \\
\hline Study area, ha & 7.7 & 9.0 & 10.0 & 9.0 & 9.0 \\
\hline Gross harvest, ton & 24.0 & 27.0 & 33.6 & 25.6 & 27.6 \\
\hline Revenue, USD & $10,752.8$ & $11,960.5$ & $15,589.2$ & $11,469.6$ & $12,696.5$ \\
\hline \multicolumn{6}{|l|}{ Variable costs, USD: } \\
\hline seeds & 537.9 & 617.4 & 748.4 & 662.3 & 667.9 \\
\hline mineral fertilizers & 2733.9 & 3106.5 & 3756.0 & 3255.8 & 2901.6 \\
\hline organic fertilizers & 47.9 & 58.1 & 62.9 & 57.4 & 56.0 \\
\hline agrochemicals & 397.0 & 462.0 & 540.4 & 471.8 & 479.8 \\
\hline fuel and lubricants & 860.2 & 830.6 & 1175.5 & 961.7 & 1005.4 \\
\hline manual labor & 3176.9 & 3586.6 & 4435.7 & 3478.9 & 3752.5 \\
\hline machines and equipment & 1536.1 & 1781.8 & 2028.6 & 1768.9 & 1832.7 \\
\hline water delivery & 39.4 & 65.6 & 69.9 & 57.7 & 62.9 \\
\hline transportation & 82.1 & 53.0 & 93.4 & 83.1 & 100.7 \\
\hline Total variable costs & 9411.3 & $10,561.5$ & $12,910.8$ & $10,797.7$ & $10,859.6$ \\
\hline \multicolumn{6}{|l|}{ Fixed costs, USD: } \\
\hline administrative costs & 386.3 & 425.2 & 619.8 & 450.8 & 446.1 \\
\hline land tax & 360.7 & 380.0 & 358.6 & 213.4 & 275.9 \\
\hline miscellaneous expenses & 282.3 & 316.8 & 387.3 & 323.9 & 325.8 \\
\hline Total fixed costs & 1029.3 & 1122.0 & 1365.7 & 988.1 & 1047.7 \\
\hline Total costs, USD & $10,440.6$ & $11,683.5$ & $14,276.5$ & $11,785.8$ & $11,907.3$ \\
\hline Net profit, USD & 312.1 & 276.9 & 1312.7 & -316.2 & 789.2 \\
\hline Net profit per 1 ha, USD & 40.5 & 30.8 & 131.3 & -35.1 & 87.7 \\
\hline Coefficient of profitability & 1.03 & 1.02 & 1.09 & 0.97 & 1.07 \\
\hline
\end{tabular}

${ }^{*}$ Currency exchange rates were downloaded on January 28, 2016 from the web-site of the Central Bank of Uzbekistan: http://cbu.uz/uzc/arkhiv-kursov-valyut/dinamika-kursov-valyut/ [5]. 
Farm profitability is directly connected to the condition of soil fertility and the source of irrigation. Their effects can be observed in Figure 8. Thus, in the Bakhodir Mirzaev farm, with the low soil quality score (41), high salinity (4.88), and poor quality of irrigation water (CDW), the yield (28.4 centner/ha) is lower than that in other farms. Hence, cotton production in this farm is unprofitable.

At the same time, we should pay attention to the Nuritdin Tanikulov farm, where under conditions of the relatively lower soil quality score (62) and slightly higher salinity (1.92) than in other farms, except the Bakhodir Mirzaev farm, high yield (33.6 centner/ha) and profitability (131.3 USD/ha) were achieved. The reasons are:

Firstly, conjunctive use of water from the collector-drainage network and SFC has a positive impact on cotton yield;

Secondly, the farm is specialized on seed growing, and the produced raw cotton is sold for seeds at higher price.

\section{Conclusion}

Taking into account the above-described analysis, a range of conclusions and proposals can be made. In particular, the share of manual labor and the rate of application of mineral fertilizers remain high. Intensive application of mineral fertilizers allows achieving high yields in the current season. However, for longer-term, their extra application does not contribute to higher yield and, in contrast, causes decrease in yields due to reduced soil fertility. In this context, innovative water- and resource-saving technologies and agronomic operations need to be introduced in cotton production. This would allow reducing manual labor inputs and improving production processes in the farms. Moreover, it is necessary to study soil fertility conditions and identify the actual soil quality scores as

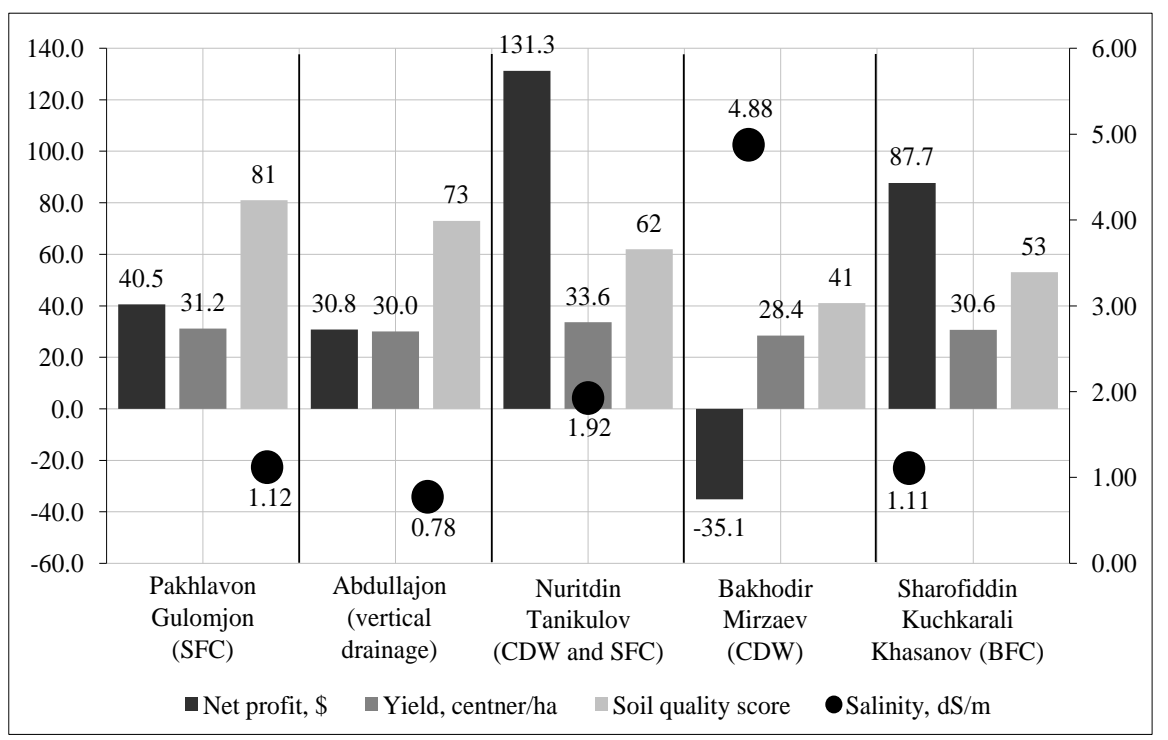

Figure 8. Relationship between the profitability of cotton farms using various sources of irrigation under conditions of different degrees of soil fertility. 
by present there are some cases, where the soil quality score is set as high, while the achieved yield is lower than the norm, even if agronomic operations are performed correctly.

\section{References}

[1] Tuchin, A.I. (2004) Drainage in the Aral Sea Basin: Towards Sustainable Development Strategy. Report by SIC ICWC; Lead Author Tuchin, A.I., Tashkent.

[2] Dukhovniy, V.A., Sokolov, V.I., Horst, M.G., Sorokin, A.G., Nazariy, A.M. and Galustyan, A.G. (2012) Dynamics of the Present Water Balance in the Ferghana Valley in the Collection of Scientific Papers. Issue 13. SIC ICWC, Tashkent, 5-27.

[3] Data of the State Statistics Committee of RUz (2015).

[4] Yakubov, M.A., Yakubov, Kh.E. and Yakubov, Sh.Kh. (2011) Collector-Drainage Flow in Central Asia and Its Use for Irrigation Purposes. SIC ICWC, Tashkent, 189.

[5] Data of the Central Bank of Uzbekistan (2015). http://cbu.uz/uzc/arkhiv-kursov-valyut/dinamika-kursov-valyut/

\section{Scientific Research Publishing}

Submit or recommend next manuscript to SCIRP and we will provide best service for you:

Accepting pre-submission inquiries through Email, Facebook, LinkedIn, Twitter, etc. A wide selection of journals (inclusive of 9 subjects, more than 200 journals)

Providing 24-hour high-quality service

User-friendly online submission system

Fair and swift peer-review system

Efficient typesetting and proofreading procedure

Display of the result of downloads and visits, as well as the number of cited articles

Maximum dissemination of your research work

Submit your manuscript at: http://papersubmission.scirp.org/

Orcontact as@scirp.org 